\title{
Influence of Pink Pigmented Facultative Methylotrophs (PPFMs) and Plant Growth Promoters on Proline, Nitrate Reductase and Catalase Activity on Semi Dry Rice
}

\author{
B. Banu Priya ${ }^{1}$, G. Balasubramanian ${ }^{2}$, P. P. Mahendran ${ }^{3}$, R. Amutha ${ }^{4}$, \\ K. Kumutha ${ }^{4}$ and S. Umesh Kannan ${ }^{5}$ \\ ${ }^{1}$ Department of Soils and Environment AC\&RI, Madurai - 625 104, India \\ ${ }^{2}$ Department of Environmental Sciences, TNAU, Coimbatore - 641 003, India \\ ${ }^{3}$ Department of Crop Management, AC \& RI, Kudumiyanmalai- 622 104, India \\ ${ }^{4}$ Agricultural College and Research Institute, Madurai- 625 104, India \\ ${ }^{5}$ Forest College and Research institute, Mettupalayam- 641 301, India
}

*Corresponding author

\section{A B S T R A C T}

\section{Keywords}

Pink pigmented facultative methylotrophs, Plant growth promoters, Proline

Article Info

Accepted:

04 November 2019

Available Online:

10 December 2019
Drought stress affects various physiological and metabolic processes in rice (Oryza sativa L.) plant. Non-availability of high-yielding varieties suitable for cultivation under drought condition lead to sharp decline in rice yield. The current study was aimed to carry out to assess the impact of PPFM and plant growth promoters on mitigating drought stress effects in semi dry rice. Field experiment was carried out in semi dry rice variety ADT 45 along with foliar spray different plant growth promoters like PPFM $\left(500 \mathrm{ml} \mathrm{ha}^{-1}\right)$, brassinolide (1 $\mathrm{ppm})$ and salicylic acid (100 ppm) under semi dry condition. The study indicated that the PPFM and plant growth promoters could effectively improve drought tolerance capacity of rice under semi dry condition. PPFM and different plant growth promoters was found to be superior in improving SPAD value and proline content. The antioxidant enzyme, catalase activity was enhanced by PPFM (500 $\mathrm{ml} / \mathrm{ha}$ ) and brassinolide $(1 \mathrm{ppm})$ treatments which had the ability to protect the plant under abiotic stress by nullifying oxidative damage. Foliar spray of PPFM $\left(500 \mathrm{ml} \mathrm{ha}^{-1}\right)$ was found effective in improving the NR activity followed by brassinolide (1ppm).

\section{Introduction}

Abiotic stress has been estimated that more than half of the yield potential of major crops is mainly affected due to unfavourable growing environments such as drought (Cortina and Culianez-Macia, 2005). The problem of drought is increasing day by day with reduction in production of crops (Qayyum and Malik, 1988). Drought stress disturbs water relations, causing a reduction in water-use efficiency. Several adaptive mechanisms have been developed within plants to counter the drought stress condition 
including the accumulation of compatible solutes such as proline. There is evidence that higher levels of proline accumulation in plants are associated with greater tolerance in drought and stimulate oxidative stress tolerance by controlling antioxidant enzymes activities (Hayat et al., 2010). The accumulation of proline also shows a role in plant growth regulation under drought stress. Drought has been shown to increase the activity of antioxidant enzymes such as Catalase (CAT) and Nitratereductase (NR). It was reported that antioxidant defence system components in plants were exaggerated differently depending on the degree of drought stress(Sharma and Dubey, 2005). There is a cumulative sign that physiological and biochemical attributes had been significantly affected under drought stress. Therefore, it is crucial for understanding the physiological and biochemical characteristics in plants to improve drought tolerance under abiotic stress. Methylobacterium species are a group of bacteria known as pink-pigmented facultative methylotrophs, or PPFMs (Green and Bousfield, 1983) and exogenous application of PPFM produces benefit in alleviating the adverse effects of drought stress and also improves germination, growth, development, quality and yield of crop plants (Hayat et al., 2010). Van Loon et al., (1998) reported that environmentally sustainable agricultural systems, the bacterial inoculants that provide cross protection against both biotic and abiotic stress would be highly preferable. Exogenously applied brassinolide alleviated the detrimental effects of drought in maize and remarkably improved the chlorophyll contents, protein, relative water contents (RWC), proline, and enzymatic antioxidants (Anjum et al., 2011). Saruhan et al., (2012) reported that the exogenous salicylic acid reduced the adverse effects of drought stress in maize and might have a key role in providing tolerance to stress by decreasing water loss and inducing the antioxidant system in plants with leaf rolling, an alternative drought protection mechanism. Application of cytokinin improves the physiological traits in terms of membrane stability index, relative water contents (RWC), and photosynthetic rate at the vegetative stage of wheat (Dwivedi et al., 2014).

\section{Materials and Methods}

The field experiments were conducted in sandy clay loam soil of farmers field, Therkutheru, Melur Block, Madurai during 2017-18 with the short duration variety ADT 45. The experiment was conducted on the basis of factorial randomized block design with three replication. The experiment was conducted with the following treatments viz., Factor 1: Soil Application $\mathrm{S}_{1}$ : $100 \%$ Recommended Dose of Fertilizer (120:40:40 $\mathrm{kg} \mathrm{ha}^{-1} \mathrm{~N}, \mathrm{P}_{2} \mathrm{O}_{5}$ and $\left.\mathrm{K}_{2} \mathrm{O}\right), \mathrm{S}_{2}: 100 \% \mathrm{RDF}+$ Azospirillum (soil application @ $2 \mathrm{~kg} \mathrm{ha}^{-1}$ ), $\mathrm{S}_{3}$ : $100 \%$ RDF+Azophos (soil application @ 2 kg $\mathrm{ha}^{-1}$ ) and $\mathrm{S}_{4}: 100 \% \mathrm{RDF}+$ Azotobacter (soil application @2 $\mathrm{kg} \mathrm{ha}^{-1}$ ), Factor 2: Foliar application $\mathrm{F}_{1}$ : PPFM (Foliar application 500 $\left.\mathrm{ml} \mathrm{ha}{ }^{-1}\right), \mathrm{F}_{2}$ : Brassinolide (1 ppm), $\mathrm{F}_{3}:$ Salicylic acid (100 ppm) and $\mathrm{F}_{4}$ : Control

The estimation of proline content was adopted by using the protocol of Bates et al., (1973) and amount of proline in the sample is expressed in $\mathrm{mg} \mathrm{g}^{-1} .0 .5 \mathrm{~g}$ leaf sample was homogenized with $10 \mathrm{~mL}$ of 3 per cent sulphosalicylic acid and centrifuged at 3000 rpm for 10 minutes. Two $\mathrm{mL}$ of the supernatant was taken and $2 \mathrm{~mL}$ of glacial acetic acid, $2 \mathrm{~mL}$ of ortho phosphoric acid and $2 \mathrm{~mL}$ of acid ninhydrin mixture were added.

The contents were allowed to react at $1000^{\circ} \mathrm{C}$ for 1 hour under water bath and then it is incubated on ice for 10 minutes to terminate the reaction. The reaction mixture was mixed vigorously with $4 \mathrm{ml}$ toluene for 15 to 20 seconds. The chromophore containing toluene 
was aspired from the aqueous phase, warmed to room temperature and optical density was read at $520 \mathrm{~nm}$.

Nitrate reductase activity was estimated in fully expanded functional leaves following the method of Nicholas et al., (1976) by using assay medium (Phosphate buffer $+\mathrm{KNO}_{3}+$ Iso propanol), sulphanilamide and $\mathrm{N}(1-$ Naphthylamino)ethylamine dihydrochloride (NEDH). The enzyme activity was expressed as $\mu \mathrm{mol} \mathrm{NO} 2 \mathrm{~g}^{-1} \mathrm{~h}^{-1}$ using $\mathrm{KNO}_{2}$ as a standard. Catalase activity was determined by following titration method using potassium permanganate (Gopalachari, 1963) and expressed as $\mu \mathrm{g} \mathrm{H}_{2} \mathrm{O}_{2} \mathrm{~g}^{-1} \min ^{-1}$. The data on various parameters were analyzed statistically as per the procedure suggested by Gomez and Gomez (1984).

\section{Results and Discussion}

\section{Impact of PPFM and plant growth} promoters on proline

Proline is believed to protect plant tissues against stress by acting as nitrogen storage, osmo regulator and protectant for enzymes and cellular structure. It is one of the important amino acids, is known to occur widely in higher plants and normally accumulates in large quantities in response to environmental stress (Ali et al., 1999).From the current study, it was noted that the higher accumulation of proline was found in semi dry condition compared to control. The maximum proline content, Azophos @ 2 kg ha-1and PPFM ranged from $1.25,3.48$ and $4.76 \mu$ mol $\mathrm{g}^{-1}$ followed by $1.21,3.34$ and $4.62 \mu \mathrm{mol} \mathrm{g}^{-1}$ were though consolidating brassinolide @ 1 ppm at 30 DAS, 60 DAS and at harvest stage exclusively (Table 1). This might be due to the fact that PPFM and plant growth promoters reduced the impact of stress leading to high level of proline accumulation. However, the proline content is higher than control in all the
PPFM and plant growth promoters treated plants. Our results are agreeable with the findings of Uyprasert et al., (2004), who stated that proline acts as a compatible solute and a protective agent for cytoplasmic enzymes and structures. The role of ameliorants such as PPFM and brassinolide was significant in increasing the content of proline in the stressed plants (Aruna et al., 1999).

These bioregulators could increase the hydrolysis of macro- molecules into the simpler ones like mono and disaccharides and amino acids especially proline etc. and consequently higher osmolyte concentration resulting in favourable osmoregulation process during water stress conditions.

Impact of PPFM and plant growth promoters on nitrate reductase and catalase activity

NR activity is vital for the metabolic and physiological status of plants and can be used as a biomarker of plant stress including drought, since, nitrate reductase activity decreases in plants exposed to water limitation (Azconet al., 1996). In the present study too the data showed a concomitant increment concerning maximum nitrate reductase activity, Azophos @ 2 kg ha ${ }^{-1}$ and PPFM ranged from 54.9, 57.8 and 55.1 $\mu \mathrm{g} \mathrm{NO}_{2} \mathrm{~g}^{-1} \mathrm{~h}^{-1}$ followed by 52.8, 56.1 and $53.3 \mu \mathrm{g} \mathrm{NO}_{2} \mathrm{~g}^{-1} \mathrm{~h}^{-}$ ${ }^{1}$ were though consolidating brassinolide @ 1 ppm at 30 DAS, 60 DAS and at harvest stage exclusively (Table 2 and 3). The optimistic role of PPFM for the protection of NR activity under drought was observed in the present study. However, the physiological basis for the protection of NR activity by PPFM will be elucidated.

The enzyme catalase involved in the detoxification of reactive oxygen species, especially hydrogen peroxide. 
Table.1 Effect of PPFMs and plant growth promoters on proline content ( $\mu$ mol g $\mathrm{g}^{-1}$ ) of semi - dry rice (pooled analysis for two years)

\begin{tabular}{|c|c|c|c|c|c|c|c|c|c|c|c|c|c|c|c|}
\hline \multirow{4}{*}{$\begin{array}{c}\text { Soil } \\
\text { application }\end{array}$} & \multicolumn{15}{|c|}{ Proline content $\left(\mu \mathrm{mol} \mathrm{g}^{-1}\right)$} \\
\hline & \multicolumn{5}{|c|}{30 DAS } & \multicolumn{5}{|c|}{60 DAS } & \multicolumn{5}{|c|}{ At harvest } \\
\hline & \multicolumn{5}{|c|}{ Foliar application } & \multicolumn{5}{|c|}{ Foliar application } & \multicolumn{5}{|c|}{ Foliar application } \\
\hline & F1 & F2 & F3 & F4 & Mean & F1 & F2 & F3 & F4 & Mean & F1 & F2 & F3 & F4 & Mean \\
\hline S1 & 0.71 & 0.66 & 0.62 & 0.54 & 0.63 & 2.35 & 2.21 & 2.13 & 2.00 & 2.17 & 3.47 & 3.37 & 3.25 & 3.07 & 3.28 \\
\hline S2 & 1.12 & 1.07 & 0.94 & 0.58 & 0.92 & 3.00 & 2.87 & 2.74 & 2.04 & 2.65 & 4.27 & 4.16 & 4.02 & 3.11 & 3.89 \\
\hline S3 & 1.25 & 1.21 & 1.16 & 0.60 & 1.05 & 3.48 & 3.34 & 3.23 & 2.08 & 3.03 & 4.76 & 4.62 & 4.44 & 3.16 & 4.24 \\
\hline S4 & 0.87 & 0.78 & 0.74 & 0.56 & 0.74 & 2.68 & 2.61 & 2.49 & 2.04 & 2.45 & 3.86 & 3.77 & 3.62 & 3.09 & 3.58 \\
\hline Mean & 0.99 & 0.93 & 0.86 & 0.57 & & 2.88 & 2.76 & 2.65 & 2.06 & & 4.09 & 3.98 & 3.83 & 3.11 & \\
\hline & $\mathbf{S}$ & $\mathbf{F}$ & $\mathbf{S} \times \mathbf{F}$ & & & $\mathbf{S}$ & $\mathbf{F}$ & $\mathbf{S} \times \mathbf{F}$ & & & $\mathbf{S}$ & $\mathbf{F}$ & $\mathbf{S} \times \mathbf{F}$ & & \\
\hline SEd & 0.01 & 0.01 & 0.02 & & & 0.03 & 0.03 & 0.06 & & & 0.04 & 0.04 & 0.09 & & \\
\hline $\begin{array}{c}\text { CD } \\
(P=0.05)\end{array}$ & 0.02 & 0.02 & 0.03 & & & 0.07 & 0.07 & 0.13 & & & 0.09 & 0.09 & 0.18 & & \\
\hline
\end{tabular}

Treatment details

$\mathrm{S1}: 100 \%$ RDF (75:25:37.5 kg ha $\left.{ }^{-1} \mathrm{~N}, \mathrm{P}_{2} \mathrm{O}_{5}, \mathrm{~K}_{2} \mathrm{O}\right)$

S2 : $100 \%$ RDF + Azospirillum (Soil application @ 2 kg ha $^{-1}$ )

S3 : $100 \%$ RDF + Azophos (Soil application @ $2 \mathrm{~kg} \mathrm{ha}^{-1}$ )

S4 : $100 \%$ RDF + Azotobacter (Soil application @ $2 \mathrm{~kg} \mathrm{ha}^{-1}$ ) 
Table.2 Effect of PPFMs and plant growth promoters on catalase activity ( $\mu \mathrm{g}$ of $\mathrm{H}_{2} \mathrm{O}_{2} \mathrm{~g}^{-1} \mathrm{~m}^{-1}$ ) of semi - dry rice (pooled analysis for two years)

\begin{tabular}{|c|c|c|c|c|c|c|c|c|c|c|c|c|c|c|c|}
\hline \multirow{4}{*}{$\begin{array}{c}\text { Soil } \\
\text { application }\end{array}$} & \multicolumn{15}{|c|}{ Catalase activity ( $\mu \mathrm{g}$ of $\mathrm{H}_{2} \mathrm{O}_{2} \mathrm{~g}^{-1} \mathrm{~m}^{-1}$ ) } \\
\hline & \multicolumn{5}{|c|}{30 DAS } & \multicolumn{5}{|c|}{60 DAS } & \multicolumn{5}{|c|}{ At harvest } \\
\hline & \multicolumn{5}{|c|}{ Foliar application } & \multicolumn{5}{|c|}{ Foliar application } & \multicolumn{5}{|c|}{ Foliar application } \\
\hline & F1 & F2 & F3 & F4 & Mean & F1 & F2 & F3 & F4 & Mean & F1 & F2 & F3 & F4 & Mean \\
\hline S1 & 23.7 & 24.2 & 24.4 & 26.6 & 24.7 & 27.4 & 27.6 & 27.9 & 30.2 & 28.2 & 25.3 & 25.6 & 25.8 & 30.2 & 26.7 \\
\hline S2 & 21.7 & 21.8 & 21.9 & 26.3 & 22.9 & 26.5 & 26.7 & 26.8 & 29.9 & 27.5 & 24.9 & 25.1 & 25.2 & 28.9 & 26.1 \\
\hline S3 & 20.2 & 20.3 & 20.4 & 25.7 & 21.6 & 26.2 & 26.4 & 26.5 & 29.4 & 27.1 & 24.5 & 24.7 & 24.9 & 28.0 & 25.5 \\
\hline S4 & 22.4 & 22.5 & 22.7 & 23.5 & 22.8 & 26.4 & 26.6 & 26.8 & 29.9 & 27.4 & 24.9 & 25.1 & 25.2 & 29.5 & 26.2 \\
\hline \multirow[t]{2}{*}{ Mean } & 22.0 & 22.3 & 22.4 & 25.5 & & 26.6 & 26.8 & 26.9 & 29.8 & & 24.9 & 25.1 & 25.3 & 29.2 & \\
\hline & $\mathbf{S}$ & $\mathbf{F}$ & $\mathbf{S} \times \mathbf{F}$ & & & $\mathbf{S}$ & $\mathbf{F}$ & $\mathbf{S} \times \mathbf{F}$ & & & $\mathbf{S}$ & $\mathbf{F}$ & $\mathbf{S} \times \mathbf{F}$ & & \\
\hline SEd & 0.22 & 0.22 & NS & & & 0.34 & 0.34 & NS & & & 0.28 & 0.28 & NS & & \\
\hline $\begin{array}{c}\text { CD } \\
(P=0.05)\end{array}$ & 0.44 & 0.44 & 0.89 & & & 0.71 & 0.71 & 1.42 & & & 0.59 & 0.59 & 1.18 & & \\
\hline
\end{tabular}

Treatment details

\begin{tabular}{|c|c|}
\hline S1 : $100 \%$ RDF $\left(75: 25: 37.5 \mathrm{~kg} \mathrm{ha}^{-1} \mathrm{~N}, \mathrm{P}_{2} \mathrm{O}_{5}, \mathrm{~K}_{2} \mathrm{O}\right)$ & F1 : PPFM (Foliar application $500 \mathrm{ml} \mathrm{ha}^{-1}$ ) \\
\hline S2 : $100 \%$ RDF + Azospirillum (Soil application @ $2 \mathrm{~kg} \mathrm{ha}^{-1}$ ) & F2 : Brassinolide ( 1 ppm) \\
\hline S3 : $100 \%$ RDF + Azophos (Soil application @ 2 kg ha $^{-1}$ ) & F3 : Salicyclic acid (100 ppm) \\
\hline S4 : $100 \%$ RDF + Azotobacter (Soil application @ $2 \mathrm{~kg} \mathrm{ha}^{-1}$ ) & F4 : Control \\
\hline
\end{tabular}


Table.3 Effect of PPFMs and growth promoters on nitrate reductase activity ( $\mu \mathrm{g}$ of $\mathrm{NO}_{2} \mathrm{~g}^{-1} \mathrm{~h}^{-1}$ )of semi - dry rice (pooled analysis for two years)

\begin{tabular}{|c|c|c|c|c|c|c|c|c|c|c|c|c|c|c|c|}
\hline \multirow{4}{*}{$\begin{array}{c}\text { Soil } \\
\text { application }\end{array}$} & \multicolumn{15}{|c|}{ Nitrate reductase activity ( $\mu \mathrm{g}$ of $\mathrm{NO}_{2} \mathrm{~g}^{-1} h^{-1}$ ) } \\
\hline & \multicolumn{5}{|c|}{30 DAS } & \multicolumn{5}{|c|}{$60 \mathrm{DAS}$} & \multicolumn{5}{|c|}{ At harvest } \\
\hline & \multicolumn{5}{|c|}{ Foliar application } & \multicolumn{5}{|c|}{ Foliar application } & \multicolumn{5}{|c|}{ Foliar application } \\
\hline & F1 & F2 & F3 & F4 & Mean & F1 & F2 & F3 & F4 & Mean & F1 & F2 & F3 & F4 & Mean \\
\hline S1 & 40.9 & 39.4 & 38.0 & 35.3 & 38.4 & 43.9 & 42.4 & 40.9 & 37.9 & 41.3 & 42.2 & 40.5 & 39.2 & 35.6 & 39.3 \\
\hline S2 & 49.9 & 48.2 & 47.3 & 36.1 & 45.4 & 52.8 & 51.4 & 48.4 & 39.3 & 47.9 & 50.5 & 48.9 & 47.5 & 36.7 & 45.9 \\
\hline S3 & 54.9 & 52.8 & 51.3 & 36.4 & 48.8 & 57.8 & 56.1 & 54.5 & 40.0 & 52.0 & 55.1 & 53.3 & 51.9 & 37.6 & 49.4 \\
\hline S4 & 45.5 & 43.9 & 42.6 & 35.9 & 41.9 & 48.5 & 46.9 & 45.4 & 38.6 & 44.8 & 46.5 & 45.0 & 43.5 & 36.4 & 42.8 \\
\hline \multirow[t]{2}{*}{ Mean } & 47.8 & 46.2 & 44.7 & 35.9 & & 50.7 & 49.2 & 47.3 & 38.9 & & 48.5 & 46.9 & 45.4 & 36.5 & \\
\hline & $\mathbf{S}$ & $\mathbf{F}$ & $\mathbf{S} \times \mathbf{F}$ & & & $\mathbf{S}$ & $\mathbf{F}$ & $\mathbf{S} \times \mathbf{F}$ & & & $\mathbf{S}$ & $\mathbf{F}$ & $\mathbf{S} \times \mathbf{F}$ & & \\
\hline SEd & 0.34 & 0.34 & 0.68 & & & 0.48 & 0.48 & 0.97 & & & 0.44 & 0.44 & 0.88 & & \\
\hline $\begin{array}{c}\text { CD } \\
(P=0.05)\end{array}$ & 0.70 & 0.70 & 1.40 & & & 0.99 & 0.99 & 1.99 & & & 0.90 & 0.90 & 1.81 & & \\
\hline
\end{tabular}

Treatment details

\begin{tabular}{|c|c|}
\hline $\mathrm{S1}: 100 \%$ RDF $\left(75: 25: 37.5 \mathrm{~kg} \mathrm{ha}^{-1} \mathrm{~N}, \mathrm{P}_{2} \mathrm{O}_{5}, \mathrm{~K}_{2} \mathrm{O}\right)$ & F1 : PPFM (Foliar application $500 \mathrm{ml} \mathrm{ha}^{-1}$ ) \\
\hline S2 : $100 \%$ RDF + Azospirillum (Soil application @ $2 \mathrm{~kg} \mathrm{ha}^{-1}$ ) & F2 : Brassinolide ( 1 ppm) \\
\hline S3 : 100 \% RDF + Azophos (Soil application @ 2 kg ha $^{-1}$ ) & F3 : Salicyclic acid (100 ppm) \\
\hline S4 : $100 \%$ RDF + Azotobacter (Soil application@ $2 \mathrm{~kg} \mathrm{ha}^{-1}$ ) & F4 : Control \\
\hline
\end{tabular}


In the present study also the data showed a concomitant increment concerning catalase activity by the combined application of soil and foliar application recorded the minimum catalase activity ranged from of 20.2, 26.2 and $24.5 \mu \mathrm{g}$ of $\mathrm{H}_{2} \mathrm{O}_{2} \mathrm{~g}^{-1} \mathrm{~m}^{-1}$ respectively, which was followed by $20.3,26.4$ and $24.7 \mu \mathrm{g}$ of $\mathrm{H}_{2} \mathrm{O}_{2} \mathrm{~g}^{-1} \mathrm{~m}^{-1}$ were though joining brassinolide @ $1 \mathrm{ppm}$ at the harvest stage. Among the enzymes, catalase (CAT) is an important and most powerful antioxidant enzyme under abiotic stress condition to nullify the effect of $\mathrm{H}_{2} \mathrm{O}_{2}$ and protects the plants under stress condition. This enzyme is generally regarded as $\mathrm{H}_{2} \mathrm{O}_{2}$ scavenger involved in the reduction of damage by oxidation function (Reddy et al., 2004). Abd El-Gawad et al., (2015) found that the antioxidant enzymes like catalase and SOD activity were increased by the PPFM in snap bean.

Agricultural production has been declined year by year due to many abiotic stresses especially drought. Of the various management practices available, mitigation through plant growth promoters and bioproducts like PPFM are promising measures to enhance water status of the plant, photosynthetic rate, compatible osmolytes namely, proline, nitrate reductase and antioxidant enzyme like catalase activity which protects the plant under any abiotic stress condition. Therefore, these results have practical field application to protect the plant under water stress condition especially PPFM. Among the treatment combinations RDF + Azophos@2 kg ha ${ }^{-1}$ with PPFM @ 500 ml ha ${ }^{1}$ haveregistered maximum proline content, nitrate reductase and catalase activity on semi dry rice.

\section{References}

Abd El-Gawad, H.G. Ibrahim, M.F. Abd ElHafez, A.A. and Abou El-Yazied, A. 2015. Contribution of Pink Pigmented
Facultative Methylotrophic Bacteria in Promoting Antioxidant Enzymes, Growth and Yield of Snap Bean. Am.Eur. J. Agric. Environ. Sci. 15 (7): 1331-1345.

Ali, G., Srivastava, P. S. and Iqbal, M. 1999. Proline accumulation, protein pattern and photosynthesis in regenerates grown under $\mathrm{NaCl}$ stress. Biol. Plant, 42: 89-95.

Anjum, S. A., Xie, X. and Wang, L. 2011. Morphological, physiological and biochemical responses of plants to drought stress. Afr. J. Agric. Res. 6: 2026-2032.

Aruna, T., Kumar, N. and Sairam, R. K. 1999. Efficacy of RWC, membrane stability, osmotic potential, endogenous ABA and root biomass as indices for selection against water stress in rice. Ind. J. Plant Physiol. 4(4): 302-306

Ashraf, M. and Foolad, M. R. 2007. Roles of glycinebetaine and proline in improving plant abiotic stress resistance. Environ. Exp. Bot. 59: 20616.

Azcon, R., Gomez, M. and Tobar, R. M. 1996. Physiological and nutritional responses by Lactuca sativa $L$. to nitrogen sources and mycorrhizal fungi under drought conditions. Biol. Fertil. Soils. 22: $156-161$

Barrs, H. D. and Weatherly, P. E. 1962. A reexamination of the relative turgidity technique for estimating water deficits in leaves. Aust. J. Biol Sci. 15: 413428.

Bartholomew, D. M., Bartley, G. E. and Scolnik, P. A. 1991. Abscisic-acid control of rbcS and cab transcript ion in tomato leaves. Plant Physiol. 96: 291-296.

Basile, D. V., Basile, M. R. Li, Q. Y. and Corpe, W. A. 1985. Vitamin B 12 stimulated growth and development of Jungermannia leiantha Grolle and 
Gymnocolea inflate Dum. (Hepaticae). Bryologist. 88: 77-81

Bates, L. S., Waldren, R. P. and Teare, I. D. 1973. Rapid determination of proline for water stress studies. Plant Soil. 39: 205-207.

Bhupinder, S. and Usha, K. 2003. Salicylic acid induced physiological and biochemical changes in wheat seedlings under water stress. Plant Growth Regul. 39:137-141.

Braun, P. and Wild, A. 1984. The influence of brassinosteroid on growth parameters of wheat and mustard plants. J. Plant Physiol. 116: 189-96.

Cortina, C. and Culianez-Macia, F.A. 2005. Tomato abiotic stress enhanced tolerance by trehalose biosynthesis. Plant Sci. 169(1): 75-82.

Dwivedi, S.K., Kumar, S. Mondal, S. Malviya, N. and Dubey, R. 2014. Physiological Basis of Cytokinin induced Drought Tolerance in Wheat (Triticum aestivumL.). J. Agri Search. 1(3): 139-144.

Gomez, K. A. and Gomez, A. A. 1984. Statistical procedures for agricultural research. ( ${ }^{\text {nd }}$ Ed.) John Wiley and sons, New York, USA.

Gopalachari, N. C. 1963. Changes in the activities of certain oxidizing enzymes during germination and seedling development of Phaseolus mungo and Sorghum. Ind. J. Exp. Biol. 1: 98-100.

Green, P. N. and Bousfield, I. J. 1983. Emendation of MethylobacteriumPatt, Cole, and Hanson 1976;
Methylobacterium rhodinum (Heumann, 1962) comb. nov.corrig.; Methylobacterium radiotolerans (Ito and lizuka, 1971) comb. nov. corrig.; and Methylobacterium mesophilicum (Austin and Good fellow 1979) comb. nov.Int. J. Syst. Bacteriol., 33: 875877.

Hayat, Q., Hayat, S. Irfan, M. and Ahmad, A. 2010. Effect of exogenous salicylic acid under changing environment: a review. Environ. Exp. Bot. 68(1): 1425.

Nicholas, J. C., Harper, J. E. and Hageman, R. H. 1976. Nitrate reductase activity in soybeans. Effect of light and temperature. Plant Physiol. 58: 731735 .

Saruhan, N., Saglam, A. and Kadioglu, A. 2012. Salicylic acid pretreatment induces drought tolerance and delays leaf rolling by inducing antioxidant systems in maize genotypes. Acta Physiologiae Plantarum. 34 (1): 97106

Uyprasert, S., Toojinda, T. Udompraset, N. Tragoonrung, S. and Vanavichit, A. 2004. Proline accumulation and rooting patterns in rice in response to water deficit under rainfed lowlands. Sci. Asia. 30: 301-311.

Van Loon, L. C., Bakker, P. A. H. M. and Pieterse, C. M. J. 1998. Systemic resistance induced by rhizosphere bacteria. Ann. Rev. Phytopath. 36: 453-483.

\section{How to cite this article:}

Banu Priya, B., G. Balasubramanian, P. P. Mahendran, R. Amutha, K. Kumutha and Umesh Kannan, S. 2019. Influence of Pink Pigmented Facultative Methylotrophs (PPFMs) and Plant Growth Promoters on Proline, Nitrate Reductase and Catalase Activity on Semi Dry Rice. Int.J.Curr.Microbiol.App.Sci. 8(12): 334-341. doi: https://doi.org/10.20546/ijcmas.2019.812.045 